\title{
PENGARUH PENAMBAHAN TEPUNG BIJI BUAH NANGKA (Artocarpus heterophyllus) PADA PEMBUATAN PAKAN IKAN TERHADAP PERTUMBUHAN DAN SINTASAN IKAN NILA (Oreochromis niloticus)
}

\author{
Pengaruh Penambahan Tepung Biji Buah Nangka (Artocarpus heterophyllus) \\ Pada Pembuatan Pakan Ikan Terhadap Pertumbuhan dan Sintasan Ikan Nila \\ (Oreochromis niloticus) \\ Yulista Lahay ${ }^{1 *}$, Hasim ${ }^{1}$, Syamsuddin ${ }^{1}$ \\ ${ }^{1}$ Jurusan Budidaya Perairan Fakultas Perikanan dan Ilmu Kelautan Universitas Negeri \\ Gorontalo \\ *Korespondensi: yulista187@gmail.com
}

\begin{abstract}
ABSTRAK
Penelitian ini bertujuan untuk mengetahui pengaruh penambahan tepung biji buah nangka (Artocarpus heterophyllus) terhadap pertumbuhan dan sintasan ikan nila (Oreochromis niloticus). Penelitian ini menggunakan metode percobaan (eksperimen). Rancangan yang digunakan dalam penelitian adalah Rancangan Acak Lengkap (RAL) menggunakan analisis sidik ragam (ANOVA) dengan 4 perlakuan dan 3 kali ulangan. Hewan uji yang digunakan adalah benih ikan nila dengan ukuran panjang $\pm 5.2 \mathrm{~cm}$ dan berat \pm 2.23 gram sebanyak 120 ekor. Perlakuan yang digunakan adalah perbedaan dosis pemberian pakan berbahan dasar tepung biji buah nangka, yaitu perlakuan A (5\%), B (7\%), C (9\%) dan D (11\%). Pelaksanaan penelitian dilakukan selama 4 minggu. Hasil penelitian menunjukkan bahwa pemberian pakan berbahan dasar tepung biji nangka dan tepung ikan dengan dosis berbeda tidak berpengaruh terhadap pertumbuhan benih ikan nila.Sintasan terbaik dihasilkan pada pemberian pakan dengan dosis $5 \%$.
\end{abstract}

Kata kunci: Ikan Nila,Tepung Biji Nangka, Pertumbuhan, Sintasan.

\begin{abstract}
This study aims to determine the effect of adding jackfruit seed flour (Artocarpus heterophyllus) to the growth and survival of tilapia (Oreochromis niloticus). This research uses an experimental method. The design used in the study was a Completely Randomized Design (CRD) using analysis of variance (ANOVA) with 4 treatments and 3 replications. Test animals used were tilapia seeds with a length of $\pm 5.2 \mathrm{~cm}$ and a weight of \pm 2.23 grams as many as 120 individuals. The treatment used is the difference in the dose of feeding based on jackfruit seed flour, namely treatment A (5\%), B (7\%), C (9\%) and D (11\%). The research was carried out for 4 weeks. The results showed that giving feed made from jackfruit seed flour and fish meal with different doses had no effect on the growth of tilapia seeds. The best survival is produced by feeding at a dose of 5\%.
\end{abstract}

Keywords: tilapia fish, jackfruit seed flour, growth, survival rate. 


\section{PENDAHULUAN}

Kegiatan perikanan budidaya merupakan salah satu kegiatan yang sedang digalahkan di Provinsi Gorontalo. Produksi perikanan budidaya di Daerah Provinsi Gorontalo dalam kurun waktu 2011-2015 mengalami kenaikan sebesar $54.38 \%$ dengan produksi $115.477,39$ ton dari keseluruhan produksi 212.427,50 ton. Salah satu jenis ikan yang dikembangkan tersebut adalah ikan nila (Anonim, 2016).

Ikan nila (Oreochromis niloticus) merupakan komoditas perikanan yang mudah dibudidayakan dan dikenal luas di masyarakat memiliki daging yang tebal, rasa yang enak serta kandungan gizi yang tinggi. Pemeliharaan ikan nila telah banyak dilakukan oleh masyarakat, selain untuk kebutuhan konsumsi, kegiatan tersebut dilakukan untuk menambah penghasilan (Rahmi, $d k k$. 2013).

Faktor utama yang dapat menentukan keberhasilan usaha budidaya ikan adalah ketersediaan pakan dalam jumlah, kualitas dan waktu yang tepat. Pakan merupakan unsur penting dalam menunjang pertumbuhan dan kelangsungan hidup ikan (Dharmawan, 2013). Tingginya harga pakan sangat berpengaruh terhadap biaya produksi dan keuntungan yang akan diperoleh dari usaha budidaya. Upaya untuk mengurangi biaya pakan dibutuhkan bahan baku pakan alternatif sebagai pengganti bahan baku. Pada umumnya bahan pakan alternatif untuk ikan berasal dari berbagai limbah yang kandungan nutrisinya dapat dimanfaatkan sebagai bahan pakan ikan (Mulyasari, $d k k$. 2013).

Tepung biji buah nangka dapat digunakan sebagai bahan alternatif dalam pembuatan pakan karena harga buah nangka yang relatif murah dan mudah didapat. Tepung biji buah nangka mengandung komponen gizi yaitu air $5.02 \%$, abu $1.97 \%$, protein $12.08 \%$, lemak $0.94 \%$, karbohidrat $79.34 \%$, dan serat kasar 2.13\% (Hadi $d k k$. 2017).

Tujuan dari penelitian ini yaitu untuk mengetahui pengaruh penambahan tepung biji buah nangka (Artocarpus heterophyllus) pada pembuatan pakan terhadap pertumbuhan ikan nila (dan mengetahui dosis pakan yang menghasilkan sintasan terbaik ikan nila.

\section{METODE PENELITIAN}

Penelitian ini dilaksanakan pada bulan Mei sampai Juni 2018 selama 4 minggu yang dilakukan di Tempat Budidaya Ikan Desa Bube, Kabupaten Bone Bolangom Provinsi Gorontalo.

Tahapan pembuatan tepung biji buah nangka mengacu pada Diah (2011) dalam Hadi $d k k$. (2017) yaitu :

1. Biji nangka yang digunakan adalah biji nangka yang berukuran normal, tekstur keras dan berwarna agak coklat yang menandakan biji cukup tua serta tidak busuk.

2. Biji nangka didapatkan dari hasil buangan masyarakat yang mengkonsumsi buah nangka di Dusun Apitalao Desa Wanggarasi Kecamatan Yipilo Kabupaten Pohuwato.

3. Biji nangka yang telah didapat dibersihkan dari kotoran dan sisa buah yang masih menempel kemudian direbus selama 30 menit dan ditiriskan selama 5 menit.

4. Kulit ari biji nangka dikupas menggunakan pisau stainlees steel kemudian diiris dengan ketebalan $0,3 \mathrm{~cm}$.

5. Hasil irisan biji nangka dikeringkan dibawah sinar matahari selama 2-3 jam.

6. Biji nangka yang telah kering dihaluskan dengan menggunakan gilingan disc mill atau blender.

7. Untuk mendapatkan hasil lebih baik lagi maka dilakukan pengayakan.

Untuk membuat pakan sebanyak 1000 gram $(1 \mathrm{~kg})$ didapatkan formulasi masing-masing bahan baku sebagai berikut: 
Tabel 1. Bahan Penyusun Pakan

\begin{tabular}{ll}
\hline Bahan & Jumlah pakan (gr) \\
\hline Tepung ikan & 470.8 \\
Tepung biji & 429.2 \\
nangka & \\
Tepung kanji & 50 \\
Premix & 50 \\
Jumlah & 1000 gram \\
\hline
\end{tabular}

Pembuatan pakan ikan nila dengan menggunakan bahan dasar tepung biji buah nangka dilakukan dengan menggunakan metode percobaan, dimana bahan dan jumlah pakan yang akan digunakan ditentukan sendiri oleh peneliti. Bahan dan alat yang akan digunakan sebelumnya telah dipersiapkan terlebih dahulu. Setelah itu masing masing bahan baku ditimbang sesuai hasil perhitungan formulasi pakan. Pembuatan pakan dilakukan dengan mencampurkan bahan-bahan tepung biji buah nangka dan tepung ikan terlebih dahulu, kemudian ditambahkan air untuk mendapatkan adonan, penambahan air dilakukan secara perlahan, diusahakan adonan tidak sampai berair, setelah itu tambahkan bahan perekat (tepung kanji) untuk merekatkan pakan selanjutnya ditambahkan bahan pelengkap (vitamin dan mineral) untuk menambah kandungan nutrisi dalam pakan. Proses pencampuran dilakukan secara merata dengan menggunakan air sebanyak \pm 500 $\mathrm{ml}$ untuk pembuatan I kg pakan.

Penelitian ini merupakan penelitian eksperimen, perlakuan penelitian sebanyak 4 perlakuan dan 3 kali pengulangan. Adapun yang menjadi variabel uji adalah dosis pemberian pakan, pakan diberikan dengan dosis 5\%, $7 \%, 9 \%$ dan $11 \%$ dari total berat tubuh. Berdasarkan SNI (2009) benih ikan nila sebaiknya diberikan pakan dengan dosis $5 \%$ dari total biomassa.

Pelaksanaan penelitian ini diawali dengan persiapan alat dan bahan yang akan digunakan. Benih ikan yang digunakan dalam penelitian ini adalah benih ikan nila yang berjumlah 120 ekor dengan ukuran panjang $\pm 5.2 \mathrm{~cm}$ dan berat \pm 2.23 gram. Padat tebar ikan sebanyak 1 ekor/liter air dengan volume wadah 10 liter menggunakan wadah berupa akuarium ukuran $30 \mathrm{~cm}$ x $20 \mathrm{~cm}$ $\mathrm{x} 25 \mathrm{~cm}$. Berdasarkan hasil penelitian yang dilakukan Karlyssa dkk. (2013) padat tebar terbaik benih ikan nila ukuran $3 \mathrm{~cm}$ adalah 2 ekor/liter. Jumlah wadah yang digunakan 12 buah yang dilengkapi dengan aerasi. Benih ikan dipuasakan selama 1 hari sebelum ditebar dan dipelihara selama 4 minggu. Pakan diberikan dengan dosis 5\%, 7\%, 9\% dan $11 \%$ dari total berat tubuh. Pemberian pakan dilakukan sebanyak 3 kali sehari yaitu pada pagi, siang dan sore hari. Berdasarkan SNI (2009) benih ikan nila sebaiknya diberikan pakan sebanyak 3 kali sehari.

Selama proses pemeliharaan beberapa kegiatan yang dilakukan adalah pengukuran panjang dan berat benih ikan nila setiap seminggu sekali. Pengukuran panjang dan berat dilakukan dengan menggunakan penggaris dan timbangan digital. Kualitas air yang diukur yaitu suhu, kandungan oksigen terlarut (DO), dan tingkat keasaman (pH). Pengukuran kualitas air dilakukan setiap minggu dan dilakukan juga penyiponan air, setiap seminggu sekali atau pada saat dilakukan pengukuran panjang dan berat ikan.

Variabel yang diamati dalam penelitian ini adalah:

1. Perhitungan pertumbuhan panjang mutlak Cholik $d k k$. (2005)

$$
\mathrm{L}=\mathrm{L}_{\mathrm{t}}-\mathrm{L}_{\mathrm{o}}
$$

Keterangan:

$\mathrm{L}_{\mathrm{t}}=$ Panjang akhir penelitian waktu minggu ke-t

$\mathrm{L}_{0}=$ Panjang awal $(\mathrm{cm})$

2. Perhitungan pertumbuhan berat mutlak menurut Cholik $d k k$. (2005):

$$
\mathrm{W}=\mathrm{W}_{\mathrm{t}}-\mathrm{W}_{\mathrm{o}}
$$

Keterangan:

$\mathrm{W}_{\mathrm{t}}=$ Berat akhir penelitian waktu

minggu ke-t

$\mathrm{W}_{\mathrm{o}}=$ Berat awal $(\mathrm{g})$ 
3. Pertumbuhan Harian (DGR)

Pertumbuhan Harian (DGR), adalah pertumbuhan benih setiap hari. Menurut Cholik $d k k$. (2005) perhitungan pertumbuhan harian menggunakan rumus:

$$
\mathrm{DGR}=\frac{L t-L o}{t}
$$

Keterangan: $\mathrm{L}_{\mathrm{t}}=$ Panjang akhir $(\mathrm{cm})$

$\mathrm{L}_{0}=$ Panjang awal $(\mathrm{cm})$

$\mathrm{t}=$ Lama pemeliharaan (hari)

$$
\mathrm{DGR}=\frac{W t-W o}{t}
$$

Keterangan:

$\mathrm{W}_{\mathrm{t}}=$ Berat akhir $(\mathrm{g})$

$\mathrm{W}_{\mathrm{o}}=$ Berat awal $(\mathrm{g})$

$\mathrm{t}=$ Lama pemeliharaan (hari)

\section{Sintasan}

Sintasan merupakan kelangsungan hidup organisme yang diuji. Menurut Cholik, dkk., (2005) sintasan dihitung dengan rumus:

$$
\mathrm{SR}=\frac{N t}{N o} x 100 \%
$$

Keterangan :

$\mathrm{SR}=\operatorname{Sintasan}(\%)$

$N_{t}=$ Jumlah akhir larva penelitian waktu ke - t

\section{$N_{o}=$ Jumlah awal larva}

Data yang diperoleh meliputi hasil pengukuran pertumbuhan panjang, pertumbuhan berat dan sintasan benih ikan nila dianalisis menggunakan Analisa Sidik Ragam. (ANOVA). Apabila terdapat pengaruh perlakuan maka akan dilanjutkan dengan uji Beda Nyata Terkecil (BNT) dengan taraf kepercayaan $99 \%$.

\section{HASIL DAN PEMBAHASAN}

\section{Analisis Proksimat Pakan}

Hasil pengujian proksimat terhadap pakan yang dibuat dari pakan berbahan tepung biji buah nangka dan tepung ikan yang dilakukan di Balai Pembinaan Pengujian Mutu Hasil
Perikanan Provinsi Gorontalo dapat dilihat pada tabel berikut:

Tabel 2 Hasil Analisis Proksimat Pakan

\begin{tabular}{ll}
\hline Kandungan nutrisi & Kadar (\%) \\
Protein & 13.38 \\
Kadar lemak & 11.97 \\
Kadar air & 7.21 \\
Kadar abu & 2.06 \\
\hline
\end{tabular}

\section{Pertumbuhan Panjang Mutlak}

Pertumbuhan panjang mutlak merupakan pertumbuhan panjang akhir dari ikan nila dikurangi dengan panjang awal pemeliharaan. Berdasarkan perhitungan panjang mutlak benih ikan nila yang dilakukan, didapatkan hasil sebagai berikut :

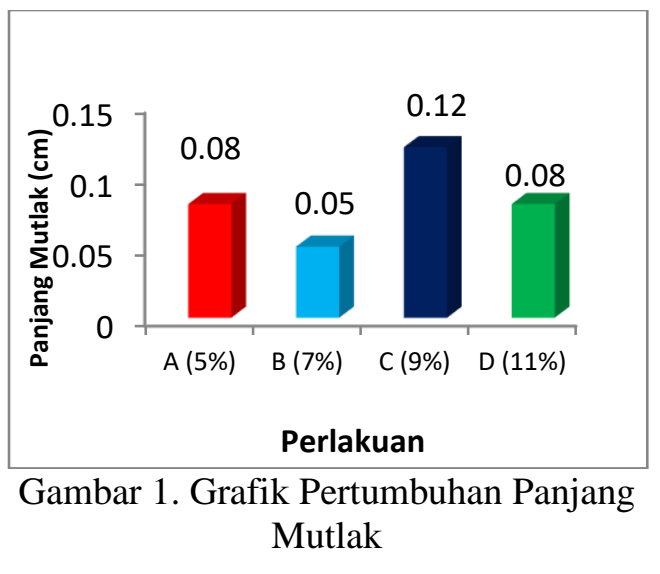

Pertumbuhan panjang mutlak pada perlakuan C (Dosis 9\%) tinggi diduga karena pakan yang diberikan mencukupi kebutuhan untuk bertumbuh, dimana pakan tersebut dapat dimanfaatkan dengan baik. Menurut Lasena dkk. (2016) ikan akan mengkonsumsi pakan hingga akan memenuhi kebutuhan energinya, sebagian besar pakan digunakan untuk proses metabolisme dan sisanya digunakan untuk beraktifitas lain seperti pertumbuhan sedangkan Sitaniapessy (2016) menyatakan pertumbuhan suatu organisme ditentukan oleh kebutuhan pakan dan jenis pakan yang dikonsumsi harus cocok dengan kebiasaan makan, apabila tidak cocok maka organisme tersebut tidak dapat memanfaatkan pakan 
yang diberikan dengan baik akibatnya pertumbuhan akan terhambat atau relatif rendah.

Perlakuan yang diberikan tidak berpengaruh terhadap pertumbuhan panjang benih ikan nila. Hal ini dikarenakan pakan yang diberikan belum bisa mendukung pertumbuhan benih ikan nila hal ini dikarenakan pakan yang diberikan hanya memiliki kandungan protein sebesar $13.38 \%$. Wibowo (2012) menyatakan pakan yang baik adalah pakan yang kandungan nutrisinya sesuai dengan kebutuhan gizi ikan. Unsur utama penunjang pertumbuhan ikan terletak pada kandungan protein dalam pakan. Pakan berkualitas mengandung asam amino yang lengkap yang akan menghasilkan pertumbuhan yang optimal.

\section{Pertumbuhan Berat Mutlak}

Pertumbuhan Berat Mutlak merupakan pertumbuhan berat yang terjadi dimana hasil tersebut didapatkan dari pengurangan pertumbuhan berat diakhir pemeliharaan dengan berat diawall pemeliharaan. Pertumbuhan berat mutlak dapat dilihat pada grafik berikut :

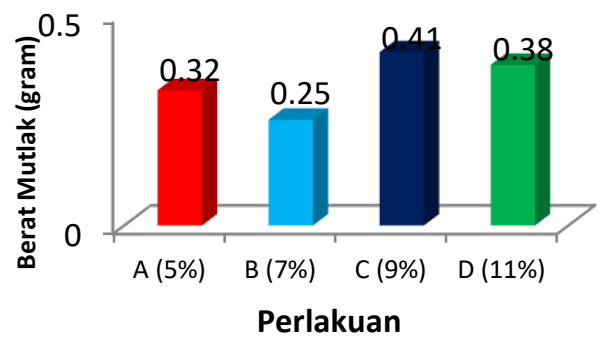

Gambar 2. Grafik Pertumbuhan Berat Mutlak

Grafik diatas menunjukkan bahwa pertumbuhan berat mutlak tertinggi terdapat pada perlakuan $\mathrm{C}$ (Dosis 9\%) dengan pertumbuhan berat mutlak 0.41 gram, kemudian perlakuan D (Dosis 11\%) dengan pertumbuhan berat mutlak 0.38 gram, setelah itu perlakuan A (Dosis 5\%) dengan pertumbuhan berat mutlak 0.32 gram dan terendah perlakuan B (Dosis 7\%) dengan pertumbuhan berat mutlak 0.25 gram.

Ikan akan bertumbuh dengan baik jika kebutuhan energy untuk bertahan hidup telah terpenuhi. Menurut Effendie (1997) dalam Ardita $d k k$. (2015), pertumbuhan dipengaruhi oleh faktor internal dan eksternal. Faktor internal sebagian besar tergantung pada kondisi tubuh ikan tersebut, misalnya kemampuan ikan dalam memanfaatkan sisa energi dan protein setelah metabolisme untuk pertumbuhannya. Sedangkan, faktor eksternal seperti faktor lingkungan dan pakan sangat berpengaruh pada pertumbuhan ikan. Kedua faktor tersebut akan menyeimbangkan keadaan tubuh ikan selama dalam media pemeliharaan dan menunjang pertumbuhan tubuh ikan nila.

Perlakuan yang diberikan tidak berpengaruh terhadap pertumbuhan berat benih ikan nila. Hal ini dikarenakan pakan yang diberikan kurang memenuhi kebutuhan ikan nila untuk bertumbuh, pakan yang diberikan pada ikan setelah dicerna akan menghasilkan energy, energy yang dihasilkan didapatkan dari protein, sisa dari energy tersebut yang digunakan untuk bertumbuh. Jika energy tidak cukup maka pertumbuhan ikan menjadi lambat.

Ardita dkk. (2015) menyatakan pertumbuhan ikan terjadi apabila ada kelebihan energi. Suatu pakan dalam mendukung pertumbuhannya, tergantung pada komposisi bahan yang digunakan, jumlah pakan, dan frekuensi pemberian pakan yang diberikan ada hubungannya dengan jenis ikan.

\section{Pertumbuhan Harian}

Pertumbuahan harian merupakan pertumbuhan yang terjadi pada setiap hari, pertumbuhan harian didapatkan dengan mengurangi pertumbuhan akhir dengan pertumbuhan awal dan dibagi dengan jumlah hari waktu pelaksanaan penelitian. Berdasarkan perhitungan pertumbuhan harian yang dilakukan, didapatkan hasil seperti pada Tabel 3 . 
Tabel 3. Data pertumbuhan harian

\begin{tabular}{ccc}
\hline Perlakuan & $\begin{array}{c}\text { Pertumbuhan } \\
\text { Panjang } \\
(\mathrm{cm})\end{array}$ & $\begin{array}{c}\text { Pertumbuhan } \\
\text { Berat }(\mathrm{gr})\end{array}$ \\
\hline A $(5 \%)$ & 0.003 & 0.011 \\
B $(7 \%)$ & 0.002 & 0.009 \\
C (9\%) & 0.004 & 0.015 \\
D (11\%) & 0.003 & 0.013 \\
\hline
\end{tabular}

Berdasarkan hasil diatas menunjukkan bahwa pertumbuhan berat harian lebih besar dari pertumbuhan panjang harian. Hal ini dikarenakan pertumbuhan lebih cepat terjadi pada pertumbuhan berat dari pada pertumbuhan panjang. Lasena $d k k$. (2016) menyatakan hubungan panjang dan berat yang terjadi pada ikan, ada yang bersifat allometrik positif yang menunjukkan bahwa pertumbuhan berat ikan lebih cepat dari pada pertumbuhan panjangnya dan allometrik negatif yang menunjukkan pertumbuhan panjang ikan lebih cepat dari pada pertumbuhan beratnya.

Menurut Kadir (2005) pakan merupakan sumber energi bagi ikan, sehingga semakin banyak pakan yang dikonsumsi maka energi yang dihasilkan juga akan semakin tinggi, pakan yang telah dikonsumsi digunakan untuk pemeliharaan tubuh, metabolisme dan pertumbuhan, ketika pakan tidak mencukupi untuk pemeliharaan tubuh dan pertumbuhan, maka pertumbuhan akan terhambat atau berhenti total.

Jeharu dkk. (2015) menyatakan kebutuhan energi ikan harus dapat dipenuhi dengan memberikan pakan berupa protein, lemak dan karbohidrat sebagai pembawa energi. Kebutuhan energi ikan dipengaruhi oleh spesies, pertumbuhan, ukuran, umur, aktivitas fisiologi, suhu dan tipe diet. Ikan stadium benih pada umumnya membutuhkan protein lebih besar, hal ini disebabkan ikan stadium benih masih membutuhkan energi protein untuk pertumbuhannya.

Hasil perhitungan protein ikan yang dilakukan didapatkan hasil sebesar $13.38 \%$ hal ini menunjukkan bahwa pakan yang diberikan kurang mampu mendukung pertumbuhan ikan nila. Menurut Mudjiman (2000) dalam Handajani (2006), bahwa pada umumnya ikan membutuhkan pakan yang kandungan proteinnya 20-25\%. Kebutuhan protein berbeda pada setiap spesies ikan, dimana pada ikan kornivora kebutuhan protein lebih tinggi bila dibandingkan dengan ikan herbivora.

\section{Sintasan}

Hasil perhitungan sintasan yang dilakukan, didapatkan hasil sebagai berikut :

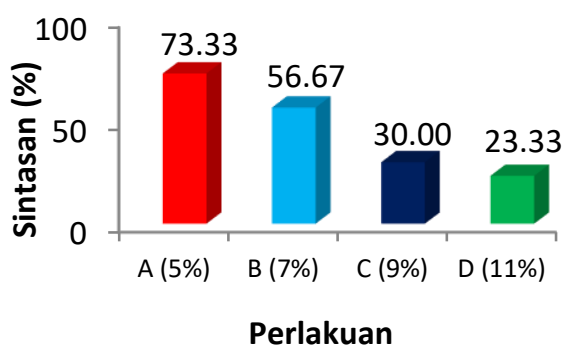

Gambar 3. Grafik Sintasan

Kelangsungan hidup (sintasan) benih ikan dipengaruhi oleh kualitas air dan jumlah pakan yang diberikan. Kondisi kualitas air yang kurang baik tidak dapat mendukung pertumbuhan ikan begitu juga dengan jumlah pakan, jika diberikan dengan jumlah banyak, maka akan mempengaruhi keadaan kualitas air.

Menurut Yustianti dkk. (2012) Faktor pertama yang mempengaruhi kehidupan ikan yaitu kualitas air, kualitas air yang baik pada media pemeliharaan akan mendukung proses metabolisme dalam proses fisiologi. Faktor kedua adalah jumlah pakan yang dikonsumsi. Selanjutnya Iskandar dan Elrifadah (2015) menambahkan sintasan atau kelangsungan hidup ikan nila sangat ditentukan oleh pakan dan kondisi lingkungan sekitar. Pemberian pakan dengan kualitas dan kuantitas yang cukup serta kondisi lingkungan yang baik, maka dapat menunjang keberlangsungan hidup ikan nila. 
Hasil perhitungan diatas menunjukkan bahwa perlakuan yang diberikan berpengaruh nyata terhadap sintasan benih ikan nila. Hal ini dikarenakan pakan yang digunakan masih mampu untuk mempertahankan kehidupan benih ikan nila, khususnya pada perlakuan A (dosis 5\%).

Menurut Hernowo dan Rachmatun (2008) dalam Yunus dkk. (2013) jika ketersediaan pakan selalu mencukupi maka tingkat keberhasilan pemeliharaan dapat mendekati $100 \%$, bahkan tidak ada yang mati atau hilang. Untuk mempertahankan kelangsungan hidup dan pertumbuhan, maka diperlukan makanan yang memenuhi kebutuhan nutrisi ikan. Makanan yang dimakan oleh ikan digunakan untuk kelangsungan hidup selebihnya dimanfaatkan untuk pertumbuhan.

\section{Kualitas Air}

Pada penelitian ini, beberapa parameter kualitas air yang diamati dapat dilihat pada tabel berikut:

Tabel 3. Parameter Kualitas Air

\begin{tabular}{ccc}
\hline Parameter & Perlakuan & Kisaran \\
\hline & A & 28.05 \\
Suhu $\left({ }^{\circ} \mathrm{C}\right)$ & B & 27.56 \\
& C & 27.48 \\
& D & 27.31 \\
\hline & A & 7.06 \\
pH & B & 6.77 \\
& C & 6.06 \\
& D & 5.87 \\
\hline & A & 5.02 \\
DO $(\mathrm{ppm})$ & B & 4.53 \\
& C & 4.25 \\
& D & 4.11 \\
\hline
\end{tabular}

Hasil pengukuran kualitas air menunjukkan bahwa terjadi perbedaan hasil disetiap perlakuan, baik parameter suhu, $\mathrm{pH}$ maupun DO. Pada perlakuan A (Dosis 5\%) dan B (Dosis 7\%) kualitas air masih cukup untuk mendukung kehidupan benih ikan nila sedangkan pada perlakuan C (Dosis 9\%) dan D (Dosis 11\%) pH air pada perlakuan tersebut tidak dapat mendukung kehidupan benih ikan nila, karena keadaannya sudah asam. Hal inilah yang menyebabkan banyaknya tingkat kematian pada perlakuan tersebut. Perubahan kualitas air tersebut diduga dikarenakan feces dan sisa pakan yang tidak terkonsumsi.

Kualitas air pemeliharaan dapat menurun dengan cepat karena sisa pakan, feses dan buangan metabolit. Hal ini tampak dari menurunnya kualitas air akibat dan tingginya kadar amonia selama pemeliharaan. Kualitas air tersebut menyebabkan keracunan atau kekurangan oksigen serta mempercepat berkembangnya bibit penyakit (Silaban $d k k$. 2012). Selanjutnya Khairuman dan Amrii (2013) menyatakan suhu air optimum untuk mendukung pertumbuhan ikan nila berkisar anatara 25-32 ${ }^{\circ} \mathrm{C}$. pH optimal untuk ikan nila adalah antara 7-8, namun demikian ikan masih mampu hidup pada pH 4-12. Kadar oksigen optimal yang dibutuhkan oleh ikan nila adalah antara $\geq 3 \mathrm{ppm}$.

Kordi (2010) dalam Hamidi (2013) pH air yang cocok dalam budidaya ikan nila adalah 6-8,5, namun pertumbuhan optimalnya terjadi pada $\mathrm{pH}$ 7-8. Nilai $\mathrm{pH}$ yang masih ditolelir nila adalah 5-11. Suhu optimal untuk pertumbuhan nila antara $25^{\circ} \mathrm{C}-30^{\circ} \mathrm{C}$. Pada suhu $22^{\circ} \mathrm{C}$, nila masih dapat memijah, begitu pula pada suhu $37^{\circ} \mathrm{C}$. Pada suhu dibawah $14^{\circ} \mathrm{C}$ atau lebih dari $38^{\circ} \mathrm{C}$, ikan nila mulai terganggu. Suhu mematikan berada pada $6^{\circ} \mathrm{C}$ dan $42^{\circ} \mathrm{C}$. Ikan nila juga dapat hidup pada perairan dengan kandungan oksigen minim yaitu lebih kecil dari 3 ppm (part per million). Oleh karena itu, ikan ini dapat dipelihara di kolam tadah hujan dan air tergenang lain yang minim oksigen, termasuk di kolam terpal. Untuk pertumbuhan optimalnya, nila membutuhkan perairan dengan kandungan oksigen minimal 3 ppm. 


\section{KESIMPULAN DAN SARAN}

Hasil perhitungan dan pembahasan yang dilakukan mendapatkan simpulan sebagai berikut :

1. Pemberian pakan berbahan dasar tepung biji nangka dan tepung ikan dengan dosis berbeda tidak berpengaruh terhadap pertumbuhan benih ikan nila.

2. Sintasan terbaik dihasilkan pada pemberian pakan dengan dosis $5 \%$.

Saran yang dapat diberikan adalah perlu dilakukan penelitian lanjutan tentang penggunaan tepung biji buah nangka sebagai bahan pembuatan pakan ikan dimana perlu penambahan tepung lainnya sebagai bahan pendamping suplai protein nabati tepung biji buah nangka tersebut, bahan pendamping tersebut seperti tepung jagung dan dedak halus. Selain itu perlu dilakukan analisis proksimat terlebih dahulu pada bahan baku pakan berupa tepung ikan agar menghasilkan pakan yang mengandung protein sesuai dengan kebutuhan ikan.

\section{DAFTAR PUSTAKA}

Anonym, 2016. Produksi Perikanan Di Gorontalo. Dinas Kelautan dan Perikanan Provinsi Gorontalo.

Ardita, N., Budiharjo, A, dan Sari, S. A. 2015. Pertumbuhan dan rasio Konversi Pakan Ikan Nila (Oreochromis niloticus) Dengan Penambahan Prebiotik. Jurusan Biologi, Fakultas Matematika dan Ilmu Pengetahuan Alam, Universitan Sebelas Maret. Bioteknologi 12 (1): 16-21, Mei 2015, ISSN: 0216-6887, EISSN: 2301-8658, DOI: 10.13057/biotek/c120103.

Cholik, F., Ateng G.J., R. P. Purnomo da n Ahmad, Z. 2005. Akuakultur Tu mpuanHarapan Masa Depan. M asyarakat Perikanan Nusantara d an Taman Akuarium Air Tawar.

Dharmawan, B. 2013. Usaha Pembuatan Pakan Ikan Konsumsi. Pustaka Baru Press. Jakarta.
Hadi, N., Yusmarini, dan Raswen, E. 2017. Pemanfaatan Tepung Biji Nangka Dan Tepung Jagung Dalam Pembuatan Flakes. Program Studi Teknologi Hasil Pertanian, Jurusan Teknologi Pertanian, Fakultas Pertanian, Universitas Riau.

Hamidi. 2013. Pengaruh Jenis Pakan Segar Yang Berbeda Terhadap Pertumbuhan Ikan Nila Gift(Oreochromis niloticus). Program Studi Perikanan Fakultas Perikanan Dan Ilmu KelautanUniversitas Teuku Umar. Skrips.

Handajani, H. 2006. Pemanfaatan Tepung Azolla Sebagai Penyusun Pakan Ikan Terhadap Pertumbuhan Dan Daya Cerna Ikan Nila Gift(Oreochiomis sp). Universitas Muhamadiyah Malang. GAMMA Volume 1, Nomor 2, September 2006: 162 170.

Iskandar, R dan Elrifadah. 2015. Pertumbuhan Dan Efisiensi Pakan Ikan Nila (Oreochromis niloticus) Yang Diberi Pakan Buatan Berbasis Kiambang. Fakultas Pertanian Universitas Achmad Yani, banjarbaru. ZIRAA'AH, Volume 40 Nomor 1, Pebruari 2015 Halaman 18-24.

Jeharu, A. A. Y., Lumenta, C dan Sampekalo, J. 2015.Pemanfaatan tepung kulit pisang kepok (Musa balbisiana colla) dalam formulasi pakan ikan nila (Oreochromis niloticus). Program Studi Budidaya Perairan FPIK Unsrat Manado. Jurnal Penelitian

Kadir, M. 2005. Penggunaan Limbah Kecap Ikan Sebagai Sumber LemakDalam Pakan Ikan PatinPangasius hypopthalmus. Program Studi Teknologi Dan Manajemen AkuakulturFakultas Perikanan Dan Ilmu KelautanInstitut Pertanian Bogor. Skripsi. 
Karlyssa, F.K., Irwanmay dan Rusdi, L. 2013. Pengaruh Padat Penebaran Terhadap Kelangsungan Hidup Dan Pertumbuhan Ikan Nila Gesit (Oreochromis niloticus). Program Studi Manajemen Sumberdaya Perairan Fakultas Pertanian Universitas Sumatera Utara.

Khairuman dan Amri Khairul, 2013.Budidaya Ikan Nila. Agromedia Pustaka. Jakarta.

Lasena, A., Nasriani, dan Irdja, A. D. 2016. Pengaruh Dosis Pakan Yang Dicampur Probiotik Terhadap Pertumbuhan Dan Kelangsungan Hidup Benih Ikan Nila (Oreochromis niloticus). Program Studi Budidaya Perairan Universitas Muhammadiyah Gorontalo. Jurnal Penelitian.

Mulyasari., Kurnia, F dan Setiawati, M. 2013. Ketercernaan Kulit Singkong Melalui Praperlakuan Kimia Dan Biologi Sebagai Bahan Pakan Ikan Nila. Departemen Budidaya Perairan, Fakultas Perikanan dan Ilmu Kelautan, Institut Pertanian Bogor. Jurnal Akuakultur Indonesia 12 (2), 178185 (2013).

Rahmi, E., Nurhadi dan Abizar. 2013. Pengaruh Pakan Dari Ampas Tahu Yang Difermentasi Dengan EM4 Terhadap Pertumbuhan Ikan Mas (Cyprinus carpio L.). Program Studi Pendidikan Biologi STKIP PGRI Sumatera Barat

Silaban, T. F., Santoso, L dan Suparmono. 2012. Dalam Peningkatan Kinerja Filter Air Untuk Menurunkan Konsentrasi Amonia Pada Pemeliharaan Ikan Mas (Cyprinus carpio). Jurusan Budidaya Perairan Unila Fakultas Pertanian Universitas Lampung.

Sitaniapessy, J. 2016. Pemberian Pakan Pelet Dan Bahan Baku Lokal Terhadap Pertumbuhan Ikan Nila (Oreochromis niloticus). Jurusan Budidaya Perairan - Sekolah Tinggi Ilmu Pertanian Santo Thomas Aquinas Jayapura. The Journal of Fisheries Development,
Juli 2016 Volume 3, Nomor $1 \mathrm{Hal}$ : $11-16$.

SNI. 2009. Produksi Ikan Nila (Oreochromis niloticus Bleeker) Kelas Pembesaran Di Kolam Air Tenang. SNI 7550 : 2009. Badan Standar Nasional.

Wibowo, K. T. 2012. Mendongkrak Produksi Lele Dengan Sistem Padat Tebar Tinggi. Jakarta : PT Agromedia Pustaka.

Yunus, T., Hasim dan Tuiyo, R. 2013. Pengaruh Padat Penebaran Yang Berbeda Terhadap Pertumbuhan Benih Ikan Lele Sangkuriang (Clarias gariepinus) Di Balai Benih Ikan (BBI) Kota Gorontalo Provinsi Gorontalo. Jurusan Teknologi Perikanan, Fakultas Ilmu-ilmu Pertanian, Universitas Negeri Gorontalo.

Yustianti., Ibrahim, M. N dan Ruslaini. 2012. Pertumbuhan dan Sintasan Larva Udang Vaname (Litopenaeus vannamei) Melalui Substitusi Tepung Ikan dengan Tepung Usus Ayam. Program Studi Budidaya Perairan FPIK Universitas Haluoleo. Jurnal Mina Laut Indonesia. 
